\title{
Article
}

\section{Synergistic effect of metallic nickel and cobalt oxides with nitrogen-doped carbon nanospheres for highly efficient oxygen evolution}

\author{
Bin Dong a,*, Jing-Yi Xie a, Zhi Tong a, Jing-Qi Chi a, Ya-Nan Zhou a, Xue Ma a, Zhong-Yuan Lin a, \\ Lei Wang b,\#, Yong-Ming Chai a \\ ${ }^{a}$ College of Science, State Key Laboratory of Heavy Oil Processing, China University of Petroleum (East China), Qingdao 266580, Shandong, China \\ ${ }^{\mathrm{b}}$ Shandong Key Laboratory of Biochemical Analysis, College of Chemistry and Molecular Engineering, Qingdao University of Science and Technology, \\ Qingdao 266042, Shandong, China
}

\section{A R T I C L E I N F O}

\section{Article history:}

Received 26 February 2020

Accepted 29 March 2020

Published 5 November 2020

\section{Keywords:}

$\mathrm{Ni} / \mathrm{Co}_{3} \mathrm{O}_{4} @ \mathrm{NC}$

$\mathrm{N}$-doped carbon

Electrocatalyst

Synergistic effect

Oxygen evolution reaction

\begin{abstract}
A B S T R A C T
The most energy-inefficient step in the oxygen evolution reaction (OER), which involves a complicated four-electron transfer process, limits the efficiency of the electrochemical water splitting. Here, well-defined $\mathrm{Ni} / \mathrm{Co}_{3} \mathrm{O}_{4}$ nanoparticles coupled with $\mathrm{N}$-doped carbon hybrids $\left(\mathrm{Ni}^{-} \mathrm{Co}_{3} \mathrm{O}_{4} @ \mathrm{NC}\right)$ were synthesized via a facile impregnation-calcination method as efficient electrocatalysts for OER in alkaline media. Notably, the impregnation of the polymer with Ni and Co ions in the first step ensured the homogeneous distribution of metals, thus guaranteeing the subsequent in situ calcination reaction, which produced well-dispersed $\mathrm{Ni}$ and $\mathrm{Co}_{3} \mathrm{O}_{4}$ nanoparticles. Moreover, the $\mathrm{N}$-doped carbon matrix formed at high temperatures could effectively prevent the aggregation and coalescence, and regulate the electronic configuration of active species. Benefiting from the synergistic effect between the $\mathrm{Ni}, \mathrm{Co}_{3} \mathrm{O}_{4}$, and $\mathrm{NC}$ species, the obtained $\mathrm{Ni} / \mathrm{Co}_{3} \mathrm{O}_{4} @ \mathrm{NC}$ hybrids exhibited enhanced OER activities and remarkable stability in an alkaline solution with a smaller overpotential of $350 \mathrm{mV}$ to afford $10 \mathrm{~mA} \mathrm{~cm}-2$, lower Tafel slope of $52.27 \mathrm{mV} \mathrm{dec}^{-1}$, smaller charge-transfer resistance, and higher double-layer capacitance of $25.53 \mathrm{mF} \mathrm{cm}-2$ compared to those of unary $\mathrm{Co}_{3} \mathrm{O}_{4} @ \mathrm{NC}$ or Ni@NC metal hybrids. Therefore, this paper presents a facile strategy for designing other heteroatom-doped oxides coupled with ideal carbon materials as electrocatalysts for the OER.

(c) 2020, Dalian Institute of Chemical Physics, Chinese Academy of Sciences. Published by Elsevier B.V. All rights reserved.
\end{abstract}

\section{Introduction}

Water oxidation, known as the anodic oxygen evolution reaction (OER), is the essential half-reaction of water electrolysis for producing high-value hydrogen energy to replace traditional fossil fuels [1-4]. However, the OER is a sluggish multistep reaction due to the complex four-electron transfer reaction $\left(2 \mathrm{H}_{2} \mathrm{O} \rightarrow 4 \mathrm{H}^{+}+\mathrm{O}_{2}+4 \mathrm{e}^{-}\right)$, which usually requires a large overpotential of more than $1.23 \mathrm{~V}$ (standard equilibrium potential) to drive the effective water electrolysis [5-8]. Therefore, to realize efficient $\mathrm{H}_{2}$ generation, one should search for effective electrode materials to reduce the overpotential for the OER

\footnotetext{
* Corresponding author. Tel/Fax: +86-532-86981156; E-mail: dongbin@upc.edu.cn

\# Corresponding author. E-mail: inorchemwl@126.com

This work was supported by Shandong Provincial Natural Science Foundation (ZR2017MB059), National Natural Science Foundation of China (21776314), the Fundamental Research Funds for the Central Universities (18CX05016A), and Postgraduate Innovation Project of China University of Petroleum (YCX2019096).

DOI: 10.1016/S1872-2067(20)63621-X | http://www.sciencedirect.com/science/journal/18722067 | Chin. J. Catal., Vol. 41, No. 11, November 2020
} 
$[9,10]$. At present, platinum group metal oxides, such as ruthenium and iridium oxides, remain the most efficient and stable catalysts for the OER [11-14]. However, considering the scarcity and high cost of these noble metal materials, it is crucial to develop naturally abundant, non-noble metal electrocatalysts to catalyze the OER on a large scale to meet the global energy demand $[15,16]$.

First-row transition-metal (Mn, Fe, Co, Ni, etc.) based compounds, such as oxides [17], (oxy)hydroxides [18,19], sulfides $[20,21]$, and phosphides [22,23], are extensively investigated as efficient OER catalysts to replace noble metal catalysts. Among these catalysts, non-noble metal oxides have accumulated more attention because recent studies have demonstrated that the real active sites for the OER may be the oxides/(oxy)hydroxides, which are formed on the surface of catalysts during the electrochemical oxidation process [24,25]. Concerning this problem, designing and tuning unique metal oxides with remarkable activities and stability for an enhanced OER have gained much focus. For example, Boettcher et al. [26] reported that cobalt oxides exhibited desirable activity in alkaline media. To maximize the activity of cobalt oxides, numerous strategies have been adopted to improve the intrinsic OER activities, including doping other transition-metals, designing unique nanostructures, and improving the conductivity of catalysts using ideal conductive materials. Hu's group reported that the intentional introduction of $\mathrm{Ni}$ or $\mathrm{Fe}$ into cobalt oxides can significantly increase their intrinsic activities, because $\mathrm{Ni}$ or Fe dopants can increase the activity of cobalt oxides related to the anodic shift in the nominally $\mathrm{Co}^{2+} /{ }^{3+}$ redox wave, indicating strong synergistic metal-metal electronic interactions between $\mathrm{Ni}$ and Co [27]. However, it is usually challenging to synthesize well-defined $\mathrm{Ni}$-doped cobalt oxides with unique structures to expose more active sites and improve the conductivity of catalysts [28]. Therefore, employing an ideal carbon substrate with high conductivity, large surface area, and strong tolerance to harsh acidic or alkaline conditions is highly desired to derive efficient Co-based hybrid catalysts. Additionally, the $\mathrm{N}$ heteroatoms doped into carbon materials can influence the electronic structures due to the different electronegativities of $\mathrm{N}$ and $\mathrm{C}$, thus activating the inert carbon surface. Organic polymers, a class of $\mathrm{N}$-doped carbon materials, have accumulated more interests due to their tunable shape, low density, high conductivity, and porous structures after undergoing carbonization at a high temperature [29-32]. The application of organic polymers relies on the design of homogeneously distributed nanostructures with porous structures and high conductivity. Furthermore, controlling the size of carbon nanostructures below $100 \mathrm{~nm}$ is essential due to the many valuable nanoscale effects [29]. Therefore, designing unique metal/nonmetal-doped oxides strongly coupled with well-defined carbon nanostructures is urgently needed, although it is still challenging.

Based on the above analysis, we have designed and synthesized well-defined $\mathrm{Ni} / \mathrm{Co}_{3} \mathrm{O}_{4} @ \mathrm{NC}$ hybrids via a facile impregnation-calcination process (Fig. 1). The first step involving polymer impregnation with $\mathrm{Ni}$ and Co ions can ensure the homogeneous distribution of metals, thus guaranteeing the following

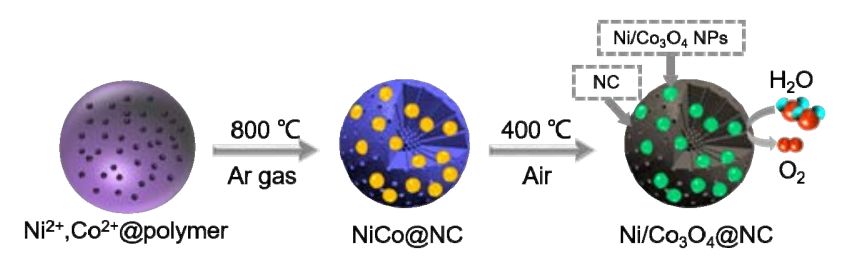

Fig. 1. Schematic illustration of the synthesis of $\mathrm{Ni} / \mathrm{Co}_{3} \mathrm{O}_{4} @ \mathrm{NC}$ nanospheres.

in situ calcination reaction, which would produce well-dispersed $\mathrm{Ni}$ and $\mathrm{Co}_{3} \mathrm{O}_{4}$ nanoparticles. Moreover, the calcination process confined within the carbon matrix can effectively prevent the aggregation and excessive growth of active species. Benefiting from the synergistic effect between $\mathrm{Ni}$, $\mathrm{Co}_{3} \mathrm{O}_{4}$, and $\mathrm{NC}$ species, the obtained $\mathrm{Ni} / \mathrm{Co}_{3} \mathrm{O}_{4} @ \mathrm{NC}$ hybrids exhibit enhanced OER activity in alkaline media, with a smaller overpotential of $350 \mathrm{mV}$ to afford $10 \mathrm{~mA} \mathrm{~cm}-2$, lower Tafel slope of $52.27 \mathrm{mV} \mathrm{dec}^{-1}$, smaller charge-transfer resistance, and higher double-layer capacitance of $25.53 \mathrm{mF} \mathrm{cm}^{-2}$ compared to those of unary $\mathrm{Co}_{3} \mathrm{O}_{4} @ \mathrm{NC}$ or $\mathrm{Ni} @ \mathrm{NC}$ metal hybrids. The present strategy may be also applicable in designing other heteroatom-doped oxides coupled with the ideal carbon materials to realize high OER electrocatalytic activities.

\section{Experimental}

\subsection{Synthesis}

The well-dispersed polymer nanospheres were synthesized via the polymerization of aniline and pyrrole using Triton $\mathrm{X}-100$ as a surfactant, according to the procedure employed in our previous study [33]. To synthesize $\mathrm{Ni}^{2+}, \mathrm{Co}^{2+} @$ polymer nanospheres, the polymer nanospheres were dispersed in 20

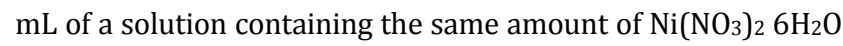
and $\mathrm{Co}\left(\mathrm{NO}_{3}\right)_{2} \cdot 6 \mathrm{H}_{2} \mathrm{O}\left(n_{\mathrm{Ni}}: n_{\mathrm{Co}}=1: 1\right)$ with strong ultrasonication to form homogeneous ink. Subsequently, the $\mathrm{Ni}^{2+}, \mathrm{Co}^{2+} @$ polymer nanospheres were obtained by evaporating the residual water at $80^{\circ} \mathrm{C}$.

A $0.2 \mathrm{~g}$ portion of the as-prepared $\mathrm{Ni}^{2+}, \mathrm{Co}^{2+} @$ polymer was calcined in a tube furnace at $800{ }^{\circ} \mathrm{C}$ for $4 \mathrm{~h}$, followed by isothermal calcination at $500{ }^{\circ} \mathrm{C}$ for $2 \mathrm{~h}$ at a heating rate of $5{ }^{\circ} \mathrm{C}$ $\mathrm{min}^{-1}$ in an inert atmosphere. After cooling to $25^{\circ} \mathrm{C}$, the product was filtered with water and $\mathrm{EtOH}$ several times and subsequently dried in a vacuum. The obtained particles were denoted as NiCo@NC nanospheres.

The NiCo@NC nanospheres were heated in a muffle furnace to $400{ }^{\circ} \mathrm{C}$ at a rate of $2{ }^{\circ} \mathrm{C} \mathrm{min-1}$, after which they were kept for $2 \mathrm{~h}$ to yield $\mathrm{Ni} / \mathrm{Co}_{3} \mathrm{O}_{4} @ \mathrm{NC}$ nanospheres.

The NCs were synthesized using the same procedure for preparing the $\mathrm{Ni} / \mathrm{Co}_{3} \mathrm{O}_{4} @ \mathrm{NC}$ nanospheres without introducing $\mathrm{Ni}\left(\mathrm{NO}_{3}\right)_{2} \cdot 6 \mathrm{H}_{2} \mathrm{O}$ and $\mathrm{Co}\left(\mathrm{NO}_{3}\right)_{2} \cdot 6 \mathrm{H}_{2} \mathrm{O}$. The $\mathrm{Ni@NC}$ and $\mathrm{Co}_{3} \mathrm{O}_{4} @ \mathrm{NC}$ nanospheres were also synthesized using the synthesis procedure for the $\mathrm{Ni} / \mathrm{Co}_{3} \mathrm{O}_{4} @ \mathrm{NC}$ nanospheres but without adding $\mathrm{Co}\left(\mathrm{NO}_{3}\right)_{2} \cdot 6 \mathrm{H}_{2} \mathrm{O}$ and $\mathrm{Ni}\left(\mathrm{NO}_{3}\right)_{2} \cdot 6 \mathrm{H}_{2} \mathrm{O}$, respectively.

\subsection{Characterizations}


The surface morphology and size of the catalysts were observed using a Hitachi S-4800 scanning electron microscope (SEM) equipped with an energy-dispersive X-ray detector (EDX) and an FEI Tecnai $\mathrm{G}^{2}$ transmission electron microscope (TEM) with an acceleration voltage of $200 \mathrm{kV}$. Powder X-ray diffraction (XRD) ( $\mathrm{Cu} K_{\alpha}, \lambda=0.154178 \mathrm{~nm}$ ) analysis was performed on an X'Pert PRO MPD diffractometer at a scanning rate of $3{ }^{\circ} \mathrm{C} \mathrm{min}-1$. The compositions and valence states were determined by X-ray photoelectron spectroscopy (XPS) (ThermoFisher Scientific II) with an Al $K_{\alpha}(1486.6 \mathrm{eV})$ X-ray source.

\subsection{Electrochemical measurements}

The electrochemical measurements of all catalysts were conducted using a Gamry Reference 600 workstation in a standard three-electrode system. $\mathrm{Hg} / \mathrm{HgO}$ and a platinum plate were used as the reference and counter electrodes, respectively. For the preparation of the working electrode, $5 \mathrm{mg}$ portions of the catalysts were dispersed in $1 \mathrm{~mL}$ of a water/ethanol/Nafion aqueous solution by strong ultrasonication to form homogeneous ink. Subsequently, $5 \mu \mathrm{L}$ of the ink was dropped onto a glassy carbon electrode (GCE) $\left(0.1256 \mathrm{~cm}^{2}\right)$ and then dried in a vacuum. The OER polarization curves of all samples were obtained in an $\mathrm{O}_{2}$-saturated $1.0 \mathrm{M} \mathrm{KOH}$ solution at a scan rate of $2 \mathrm{mV} \mathrm{s}^{-1}$. Electrochemical impedance spectroscopy (EIS) measurements were carried out at $1.4 \mathrm{~V}$ (vs. RHE) with a frequency in the range of $100000-0.1 \mathrm{~Hz}$ with an $\mathrm{AC}$ voltage of $5 \mathrm{mV}$. The estimation of the electrochemical surface area of the catalysts was carried out by cyclic voltammetry (CV) in the non-Faradaic region at various scan rates $(40,60$, $80,100,120$, and $140 \mathrm{mV} \mathrm{s}^{-1}$ ). Long-term stability tests were conducted by continuous $\mathrm{CV}$ at a scan rate of $100 \mathrm{mV} \mathrm{s}^{-1}$ from $1.3 \mathrm{~V}$ to $1.6 \mathrm{~V}$ (vs. RHE) for 1000 cycles.

\section{Results and discussion}

\subsection{Characterization of $\mathrm{Ni} / \mathrm{Co}_{3} \mathrm{O}_{4} @ \mathrm{NC}$ nanospheres}

SEM is firstly employed to examine the morphologies and compositions of the as-synthesized products, as illustrated in Fig. 2. As shown in Figs. 2(a) and 2(b), the polymer nanospheres are composed of well-dispersed nanospheres with a diameter of $\sim 100 \mathrm{~nm}$, and the surface is smooth. After impregnation with $\mathrm{Ni}$ and Co ions, followed by calcination at high temperatures, the obtained NiCo@NC nanospheres still preserve their spherical morphology but with a shrunken size of $\sim 90 \mathrm{~nm}$ (Figs. 2(c) and 2(d)). Despite the harsh thermal condition, the final as-synthesized $\mathrm{Ni} / \mathrm{Co}_{3} \mathrm{O}_{4} @ \mathrm{NC}$ nanospheres maintain their uniform nanospherical structures, while their surfaces become rougher, indicating the stable properties of the polymer framework (Figs. 2(e) and 2(f)). To further confirm the existence and homogeneous distribution of elements, the SEM images and elemental mappings of $\mathrm{Ni} / \mathrm{Co}_{3} \mathrm{O}_{4} @ \mathrm{NC}$ are presented. Fig. 2(g) displays the homogeneous distribution of the $\mathrm{Ni}, \mathrm{Co}, \mathrm{C}, \mathrm{N}$, and $\mathrm{O}$ elements of the $\mathrm{Ni} / \mathrm{Co}_{3} \mathrm{O}_{4} @ \mathrm{NC}$ nanospheres, which may be because $\mathrm{Ni}^{2+}$ and $\mathrm{Co}^{2+}$, dispersed in the polymer in an atomic scale, promote the good dispersion of the
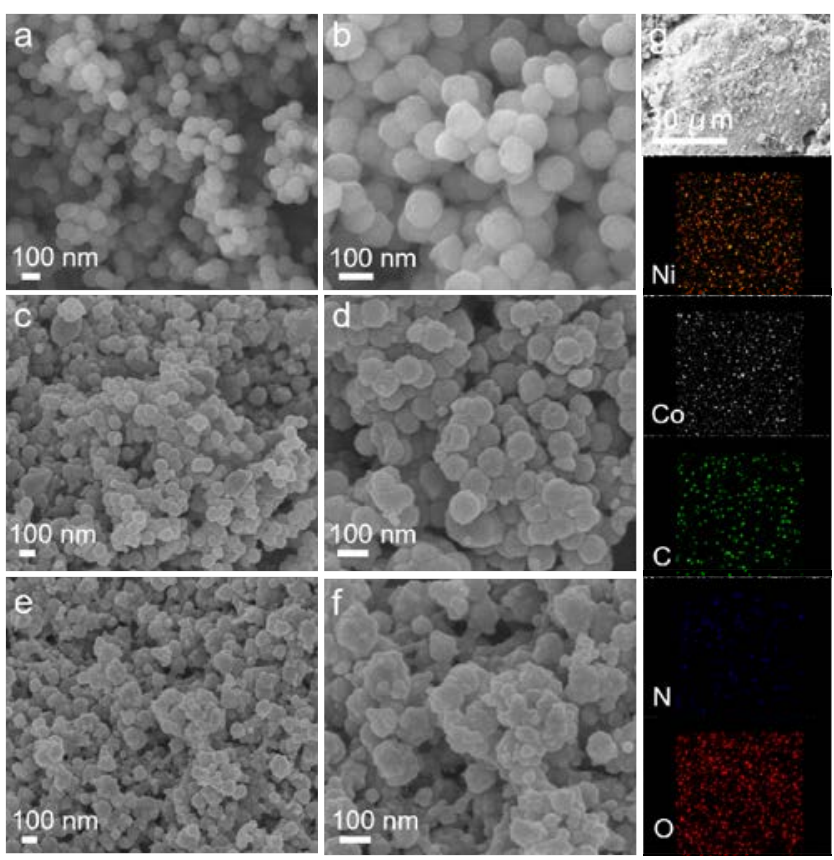

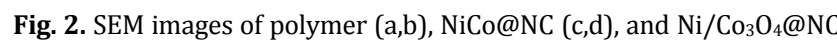
(e,f); (g) SEM mapping of $\mathrm{Ni} / \mathrm{Co}_{3} \mathrm{O}_{4} @ \mathrm{NC}$.

elements in the $\mathrm{Ni} / \mathrm{Co}_{3} \mathrm{O}_{4} @ \mathrm{NC}$ nanospheres. The EDX spectrum of Ni/ $\mathrm{Co}_{3} \mathrm{O}_{4} @ \mathrm{NC}$ in Fig. $\mathrm{S} 1$ also demonstrates the existence and contents of $\mathrm{Ni}, \mathrm{Co}, \mathrm{C}, \mathrm{N}$, and $\mathrm{O}$. For comparison, the SEM images of $\mathrm{NC}, \mathrm{Ni} @ \mathrm{NC}$, and $\mathrm{Co}_{3} \mathrm{O}_{4} @ \mathrm{NC}$ reveal that these samples also maintain the spherical morphology, implying that both $\mathrm{Ni}$ and Co species have no notable effect on the spherical polymer framework (Figs. S2-S4). Figs. S5 and S6 exhibit the homogeneous elemental distribution and contents of the Ni@NC and $\mathrm{Co}_{3} \mathrm{O}_{4} @ \mathrm{NC}$ catalysts, respectively.

The nanostructures of the as-prepared catalysts are further examined by TEM. Figs. 3(a) and 3(b) show that the polymer nanospheres exhibit the typical spherical morphology with a diameter of $\sim 100 \mathrm{~nm}$, which is consistent with the SEM analysis. After the calcination of the $\mathrm{Ni}^{2+}, \mathrm{Co}^{2+} @$ polymer nanospheres, many nanoparticles are homogeneously dispersed throughout the nanospheres (Fig. 3(c)). Under high magnification (Fig. 3(d) and Fig. S7), numerous Ni and Co nanoparticles are embedded in several carbon layers. Benefiting from the homogeneous distribution of $\mathrm{Ni}$ and $\mathrm{Co}$ nanoparticles in $\mathrm{Ni}$ $\mathrm{Co} @ \mathrm{NC}$, the as-synthesized $\mathrm{Ni} / \mathrm{Co}_{3} \mathrm{O}_{4} @ \mathrm{NC}$ nanospheres deriving from NiCo@NC also maintain a spherical morphology with many nanoparticles well-dispersed throughout the carbon matrix, and the surface is evidently porous (Fig. 3(e) and Fig. 3(f)). It is worth noting that the carbon matrix can significantly confine the excessive growth of these nanoparticles and prevent their stacking and coalescence. Moreover, Fig. 3(g) exhibits the noticeable lattice fringes with spacings of 0.204 and $0.243 \mathrm{~nm}$, which correspond to the (111) crystal plane of Ni and the (311) crystal plane of $\mathrm{Co}_{3} \mathrm{O}_{4}$, respectively. The XRD patterns of all the samples are also presented to further verify the crystallographic structures of the catalysts. As shown in Fig. S8, NC exhibits a broad peak at $\sim 24^{\circ}$, corresponding to the (002) facets of graphitic carbon. For NiCo@NC, the typical peaks located at 

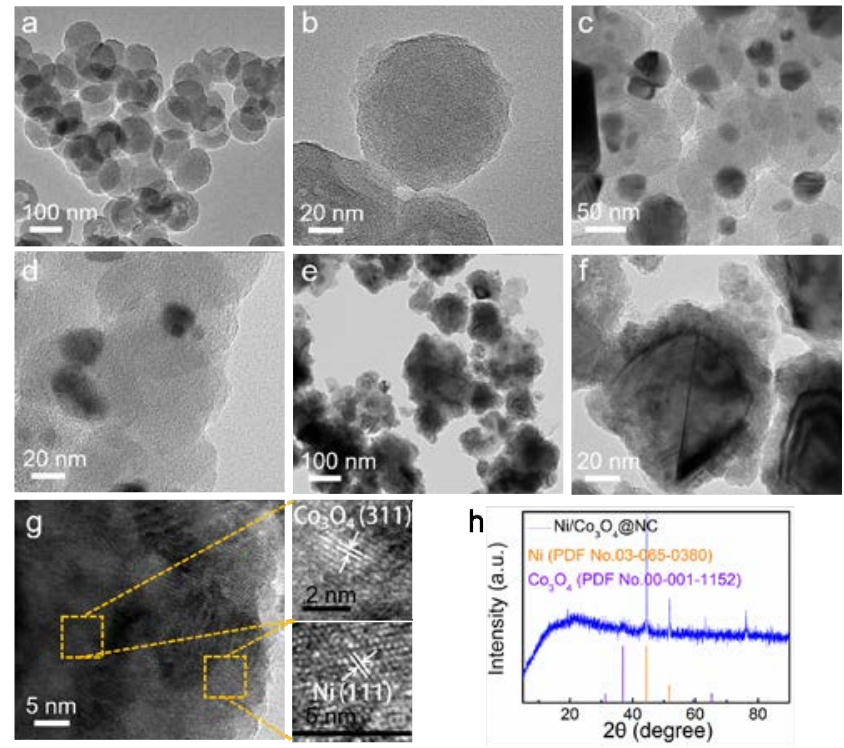

Fig. 3. TEM images of polymer (a,b), NiCo@NC (c,d), and $\mathrm{Ni} / \mathrm{Co}_{3} \mathrm{O}_{4} @ N C$ $(\mathrm{e}, \mathrm{f})$; (g) HRTEM image of $\mathrm{Ni} / \mathrm{Co}_{3} \mathrm{O}_{4} @ \mathrm{NC}$; (h) XRD patterns of NC, Ni$\mathrm{Co@NC,} \mathrm{and} \mathrm{Ni} / \mathrm{Co}_{3} \mathrm{O}_{4} @ \mathrm{NC}$.

$44.4^{\circ}, 51.7^{\circ}$, and $76.2^{\circ}$ can be ascribed to the mixture of Ni (PDF No. 01-089-7128) and Co (PDF No. 01-089-4307). After annealing of NiCo@NC, the typical peaks at $44.5^{\circ}, 51.7^{\circ}$, and $76.2^{\circ}$ of the as-prepared $\mathrm{Ni} / \mathrm{Co}_{3} \mathrm{O}_{4} @ \mathrm{NC}$ correspond to the (111), (200), and (220) planes of Ni (PDF No. 01-089-7128), respectively. Moreover, the peaks at $37.1^{\circ}, 59.2^{\circ}$, and $65.2^{\circ}$ can be ascribed to the (311), (511), and (440) facets of $\mathrm{Co}_{3} \mathrm{O}_{4}$ (PDF No. 00-001-11152), respectively, which is consistent with the TEM results (Fig. 3(h)). This result indicates that the Co species are more easily oxidized during the annealing process. In addition, the XRD patterns of the reference samples show that the $\mathrm{Ni@NC} \mathrm{nanospheres} \mathrm{are} \mathrm{composed} \mathrm{of} \mathrm{metallic} \mathrm{Ni} \mathrm{and} \mathrm{that} \mathrm{the}$ $\mathrm{Co}_{3} \mathrm{O}_{4} @ \mathrm{NC}$ nanospheres consist of $\mathrm{Co}_{3} \mathrm{O}_{4}$ (Fig. S9).

XPS measurements are further carried out to investigate the composition and valence states of the $\mathrm{Ni} / \mathrm{Co}_{3} \mathrm{O}_{4} @ \mathrm{NC}$ catalyst. As shown in Fig. 4(a), the XPS survey demonstrates the existence of $\mathrm{Ni}, \mathrm{Co}, \mathrm{C}, \mathrm{N}$, and $\mathrm{O}$ in the $\mathrm{Ni} / \mathrm{Co}_{3} \mathrm{O}_{4} @ \mathrm{NC}$ catalyst, which is consistent with the SEM mapping analysis. For $\mathrm{Ni} 2 p$ in Fig. 4(b), the peaks located at 855.7 and $873.2 \mathrm{eV}$ are assigned to $\mathrm{Ni}$ $2 p_{3 / 2}$ and $\mathrm{Ni} 2 p_{1 / 2}$, respectively, which are ascribed to $\mathrm{Ni}^{0}$ $[34,35]$. Moreover, the peaks located at $856.8 \mathrm{eV}$ in the $\mathrm{Ni} 2 p_{3 / 2}$ region and $874.5 \mathrm{eV}$ in the $\mathrm{Ni} 2 p_{1 / 2}$ region correspond to $\mathrm{Ni}^{3+}$, whose formation is due to the surface oxidation; the Ni oxides cannot be observed in the XRD pattern due to their amorphous state [36]. The existence of the low-valence $\mathrm{Ni}^{0}$ in further oxidation may play a crucial role in enhancing the OER performance, while the high-valence $\mathrm{Ni}^{3+}$ may be inactive for the OER due to the difficulties associated with its oxidation. The other two peaks located at 861.7 and $880.1 \mathrm{eV}$ are satellite peaks $[37,38]$. In addition, the high-resolution XPS spectra of the Co $2 p$ region can be fitted with two different doublets (Fig. 4(c)): one doublet located at 780.6 and $795.4 \mathrm{eV}$, ascribed to $\mathrm{Co}_{3} \mathrm{O}_{4}$; and the other doublet located at 782.3 and $796.9 \mathrm{eV}$, assigned to $\mathrm{Co}^{3+}$ [39]. Two other peaks located at 786.4 and $803.4 \mathrm{eV}$ are assigned to the satellite peaks of Co $2 p$ [40]. The high-resolution XPS spectra of $\mathrm{C} 1 s$ can be deconvoluted into four peaks, located at $284.6 \mathrm{eV}$ for $\mathrm{C}=\mathrm{C}, 285.0 \mathrm{eV}$ for $\mathrm{C}-\mathrm{O}, 286.0$ $\mathrm{eV}$ for $\mathrm{C}-\mathrm{C}$, and $228.4 \mathrm{eV}$ for $\mathrm{C}-\mathrm{N}$, respectively (Fig. 4(d)) [41]. This result demonstrates that the heteroatom $\mathrm{N}$-doped into the carbon matrix successfully. This can also be verified in the XPS spectra of the $\mathrm{N} 1 \mathrm{~s}$ region, which can be deconvoluted into three peaks of pyridinic-N (398.6 eV), graphitic-N (399.4 eV),
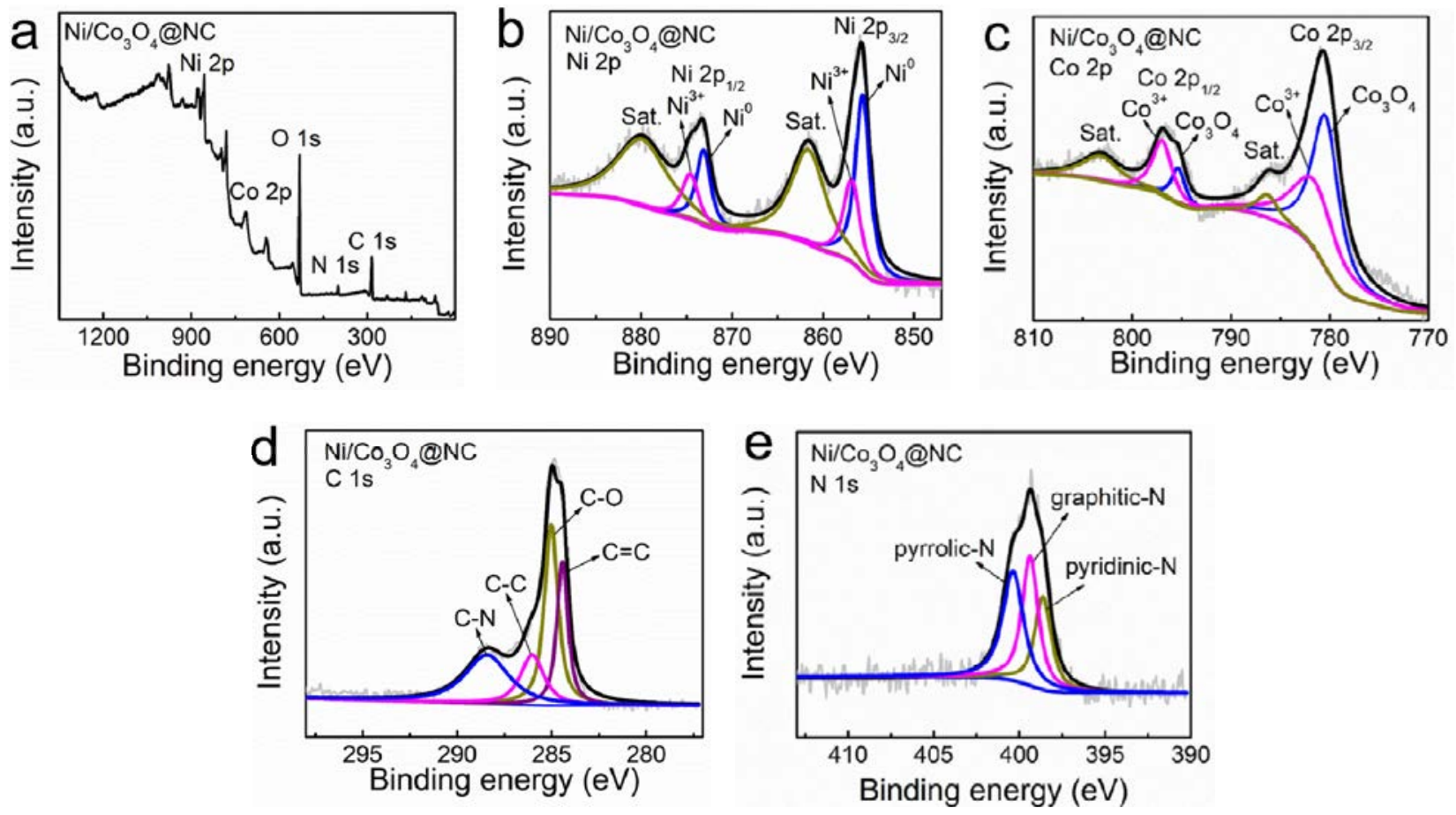

Fig. 4. Survey XPS spectrum (a) and high-resolution XPS spectrum of Ni/Co $\mathrm{O}_{4} @ \mathrm{NC}$ at the Ni $2 p$ (b), Co $2 p$ (c), C $1 s$ (d), and N $1 s$ (e) regions. 
and pyrrolic-N (400.4 eV) (Fig. 4(e)) [42]. Notably, introducing electron-rich $\mathrm{N}$ dopants is beneficial for optimizing the electron configuration, and thus accomplishing intrinsic enhanced OER performance [43]. Overall, the exact composition of the $\mathrm{Ni} / \mathrm{Co}_{3} \mathrm{O}_{4} @ \mathrm{NC}$ catalyst has been confirmed as a hybrid of $\mathrm{Ni}$ and $\mathrm{Co}_{3} \mathrm{O}_{4}$, as verified by HRTEM, XRD, and XPS analyses.

To evaluate the electrocatalytic OER performance of $\mathrm{Ni} / \mathrm{Co}_{3} \mathrm{O}_{4} @ \mathrm{NC}$, we utilize a three-electrode configuration with the scan rate of $2 \mathrm{mV} \mathrm{s}^{-1}$ in $1.0 \mathrm{M} \mathrm{KOH}$. The OER performance of bare GCE, NC, NiCo@NC, $\mathrm{Co}_{3} \mathrm{O}_{4} @ \mathrm{NC}$, and $\mathrm{Ni@NC}$ are also presented as a comparison (Fig. 5(a)). The linear sweep voltammetry (LSV) curves of all the samples show that $\mathrm{Ni} / \mathrm{Co}_{3} \mathrm{O}_{4} @ \mathrm{NC}$ exhibits a much higher current density $(j)$ at the same overpotential $(\eta)$ compared with other reference samples (Fig. 5(a)). To reach a current density of $10 \mathrm{~mA} \mathrm{~cm}^{-2}, \mathrm{Ni} / \mathrm{Co}_{3} \mathrm{O}_{4} @ \mathrm{NC}$ only requires a small overpotential of only $350 \mathrm{mV}$ compared to those of $\mathrm{NiCo} / \mathrm{NC}(510 \mathrm{mV}), \mathrm{Co}_{3} \mathrm{O}_{4} @ \mathrm{NC}(400 \mathrm{mV})$, and $\mathrm{Ni} @ \mathrm{NC}$ (480 mV) (Fig. 5(b)), suggesting that the synergistic effect between $\mathrm{Ni}, \mathrm{Co}_{3} \mathrm{O}_{4}$, and $\mathrm{NC}$ contributes significantly to the enhanced OER performance. Bare GCE exhibits nearly no current response even with a large overpotential, excluding the effect of bare GCE on the excellent OER performance of $\mathrm{Ni} / \mathrm{Co}_{3} \mathrm{O}_{4} @ \mathrm{NC}$. As shown in Table S1, the OER performance of the $\mathrm{Ni} / \mathrm{Co}_{3} \mathrm{O}_{4} @ \mathrm{NC}$ hybrids is superior to those of many other Co-based materials, suggesting the advantages of employing $\mathrm{Ni} / \mathrm{Co}_{3} \mathrm{O}_{4} @ \mathrm{NC}$ hybrids as efficient OER catalysts. The Tafel slope simulated from the LSV curve via the Tafel equation $(\eta=\mathrm{a}$ + blogj, where a represents the intercept and b represents the Tafel slope) is an inherent property to elucidate the possible reaction mechanism [1]. As observed in Figs. 5(c) and 5(d), the

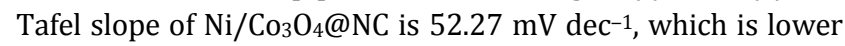

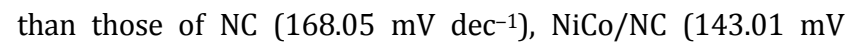
$\left.\mathrm{dec}^{-1}\right), \mathrm{Co}_{3} \mathrm{O}_{4} @ \mathrm{NC}\left(62.55 \mathrm{mV} \mathrm{dec}^{-1}\right)$, and Ni@NC (114.89 mV $\mathrm{dec}^{-1}$ ), demonstrating the favorable OER kinetics of the $\mathrm{Ni} / \mathrm{Co}_{3} \mathrm{O}_{4} @ \mathrm{NC}$ electrode. Therefore, compared with $\mathrm{NC}$, $\mathrm{Co}_{3} \mathrm{O}_{4} @ \mathrm{NC}$, and $\mathrm{Ni} @ \mathrm{NC}$, it can be speculated that $\mathrm{Ni}, \mathrm{Co}_{3} \mathrm{O}_{4}$, and NC can synergistically boost the OER performance.

To evaluate the electrochemical surface area (ECSA) of the interface between the catalysts and electrolyte, the double-layer capacitances $\left(C_{\mathrm{dl}}\right)$ of the catalysts were obtained by $\mathrm{CV}$ at different scan rates $\left(40,60,80,100,120\right.$, and $\left.140 \mathrm{mV} \mathrm{s}^{-1}\right)$ due to the proportional relationship between the ECSA and $C_{\mathrm{dl}}$ (Fig. 6(a)) [3]. The $C_{\text {dl }}$ value of $\mathrm{Ni} / \mathrm{Co}_{3} \mathrm{O}_{4} @ \mathrm{NC}$ was calculated to be $25.53 \mathrm{mF} \mathrm{cm}^{-2}$, which is much higher than those of $\mathrm{NC}(1.81$ $\mathrm{mF} \mathrm{cm}{ }^{-2}$ ), NiCo/NC (1.78 mF cm-2), $\mathrm{Co}_{3} \mathrm{O}_{4} @ \mathrm{NC}(15.28 \mathrm{mF}$ $\mathrm{cm}^{-2}$ ), and Ni@NC (2.70 mF cm${ }^{-2}$ ) (Fig. 6(b)). Accordingly, the calculated ECSA values of all the samples are listed in Table S2. Such a high ECSA value of $\mathrm{Ni} / \mathrm{Co}_{3} \mathrm{O}_{4} @ \mathrm{NC}$ implies the existence of additional exposed active sites, which can be ascribed to the strong coupling of $\mathrm{Ni} / \mathrm{Co}_{3} \mathrm{O}_{4}$ with the $\mathrm{NC}$ matrix, thus boosting the OER performance. To further reflect the intrinsic activities of all the samples, we calculate their electrocatalytic activities, where the current density is normalized to the ECSA. As is shown in Table S2 and Fig. S10, Ni/Co $\mathrm{C}_{4} @ \mathrm{NC}$ exhibits a higher current density $(j)$ at the same overpotential $(\eta)$ compared with other samples, which is consistent with the current density normalized to the geometric area of the electrode, demonstrating the superior performance of the $\mathrm{Ni} / \mathrm{Co}_{3} \mathrm{O}_{4} @ \mathrm{NC}$ hy-
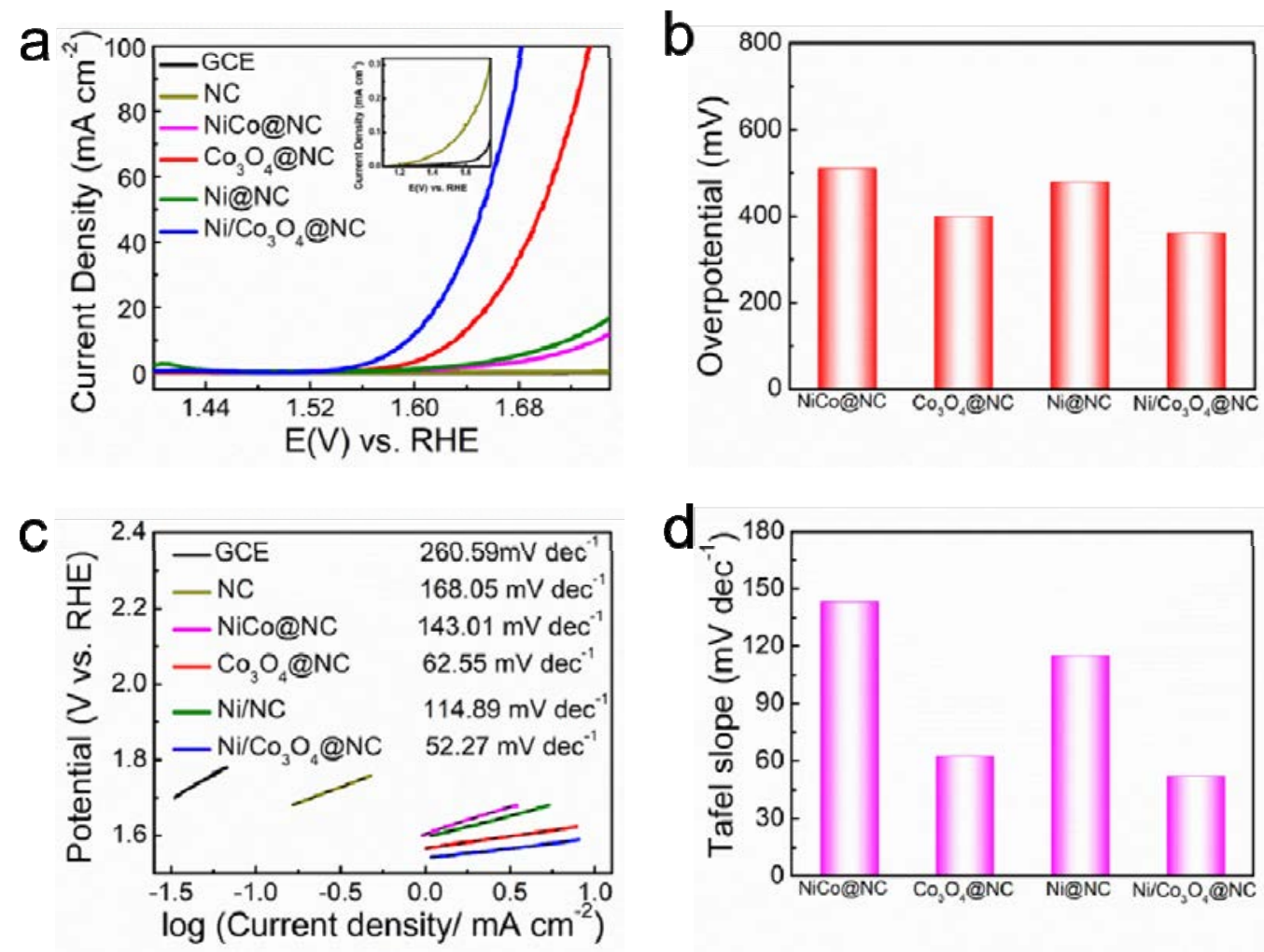

Fig. 5. (a) OER polarization curves of GCE, $\mathrm{NC}, \mathrm{NiCo} @ \mathrm{NC}, \mathrm{Co}_{3} \mathrm{O}_{4} @ \mathrm{NC}, \mathrm{Ni} @ \mathrm{NC}$, and $\mathrm{Ni} / \mathrm{Co}_{3} \mathrm{O}_{4} @ \mathrm{NC}$ in $1.0 \mathrm{M} \mathrm{KOH}$; (b) Overpotentials at $j=10 \mathrm{~mA} \mathrm{~cm}{ }^{-2}$ of $\mathrm{NiCo} @ \mathrm{NC}, \mathrm{Co}_{3} \mathrm{O}_{4} @ \mathrm{NC}, \mathrm{Ni} @ \mathrm{NC}$, and $\mathrm{Ni} / \mathrm{Co}_{3} \mathrm{O}_{4} @ \mathrm{NC} ;(\mathrm{c}, \mathrm{d})$ Corresponding Tafel plots. 

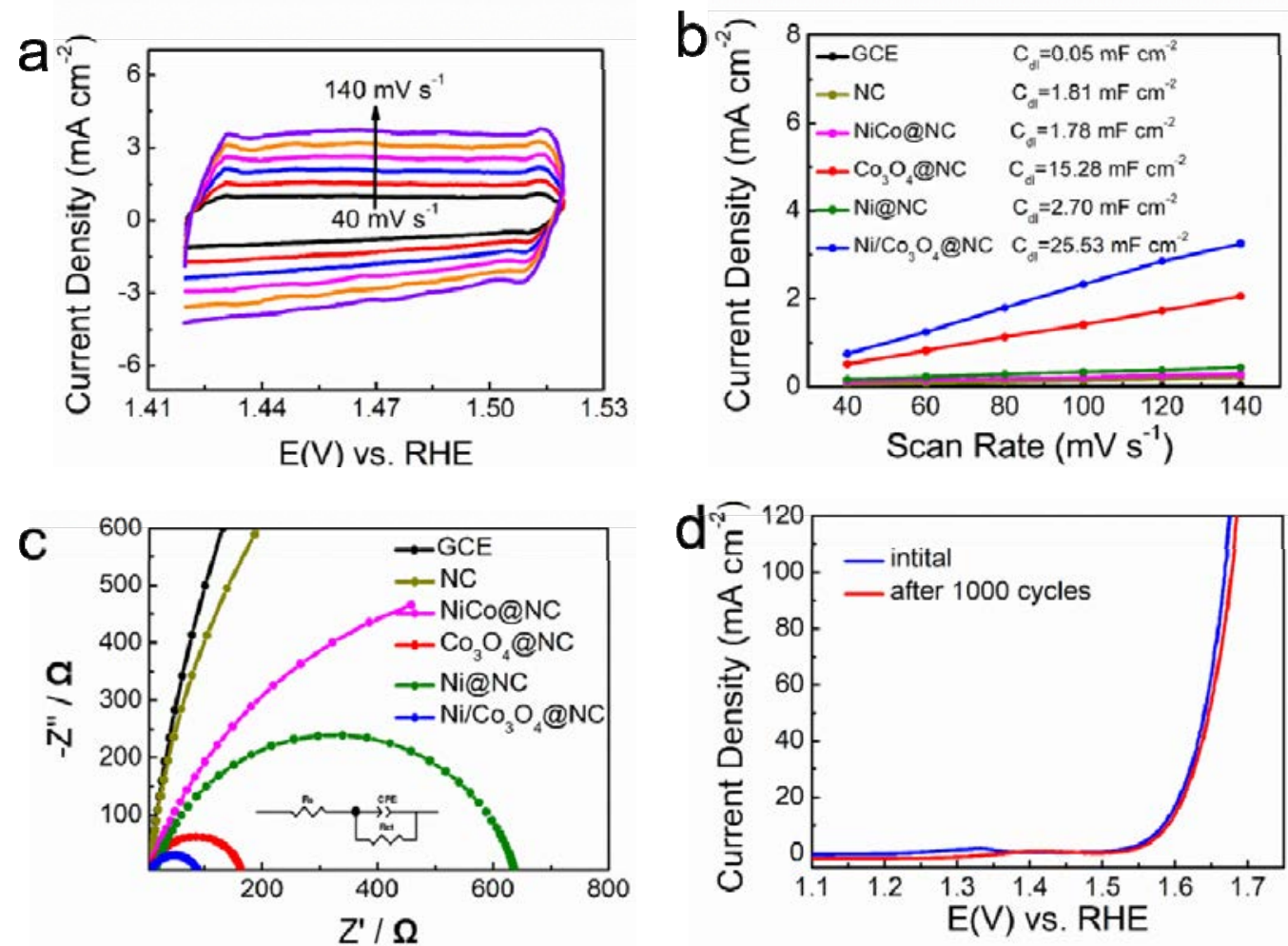

Fig. 6. (a) CVs of $\mathrm{Ni} / \mathrm{Co}_{3} \mathrm{O}_{4} @ \mathrm{NC}$ with different rates from 40 to $140 \mathrm{mV} \mathrm{s}{ }^{-1}$ in $1.0 \mathrm{M} \mathrm{KOH}$; Double-layer capacitances (b) and Nyquist plots (c) of GCE,

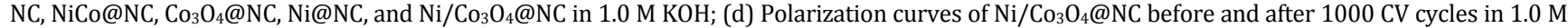
$\mathrm{KOH}$.

brids.

To elaborate on the intrinsic activities of the catalysts toward the OER, the charge-transfer resistances $\left(R_{\mathrm{ct}}\right)$ were obtained by fitting the equivalent circuit according to the EIS plots (Fig. 6(c)). Ni/Co3 $\mathrm{O}_{4} @ \mathrm{NC}$ exhibits a much smaller semicircle compared with other reference catalysts, which implies a considerably small $R_{c t}$ value, indicating an effective electron transfer process between the catalysts and electrolyte, effective Faradic process, and favorable OER kinetics. The heterostructured Ni/ $\mathrm{Co}_{3} \mathrm{O}_{4} @ \mathrm{NC}$ exhibits a highly decreased $R_{\mathrm{ct}}$ value compared with $\mathrm{Ni} @ \mathrm{NC}$ or $\mathrm{Co}_{3} \mathrm{O}_{4} @ \mathrm{NC}$, which may be related to the better contact among $\mathrm{Ni}, \mathrm{Co}_{3} \mathrm{O}_{4}$, and $\mathrm{NC}$. The metallic Ni combined with $\mathrm{Co}_{3} \mathrm{O}_{4}$ induces strong synergistic metal-metal electronic interactions between $\mathrm{Ni}$ and $\mathrm{Co}_{3} \mathrm{O}_{4}$, thus accelerating the charge-transfer rate. The charge-transfer rate of the heterostructured $\mathrm{Ni} / \mathrm{Co}_{3} \mathrm{O}_{4} @ \mathrm{NC}$ can be further decreased when coupling $\mathrm{Ni} / \mathrm{Co}_{3} \mathrm{O}_{4}$ with the highly conductive NC materials. Durability is also an important criterion in evaluating the performance toward the OER. Therefore, the stability of $\mathrm{Ni} / \mathrm{Co}_{3} \mathrm{O}_{4} @ \mathrm{NC}$ is tested through continuous CV for 1000 cycles in $1.0 \mathrm{M} \mathrm{KOH}$. As shown in Fig. 6(d), the LSV curve of $\mathrm{Ni} / \mathrm{Co}_{3} \mathrm{O}_{4} @ \mathrm{NC}$ remains nearly unchanged after continuous 1000 cycles. This may be due to the intimate combination among $\mathrm{Ni}, \mathrm{Co}_{3} \mathrm{O}_{4}$, and $\mathrm{NC}$ that prevents the agglomeration and corrosion of active species.

\section{Conclusions}

In summary, $\mathrm{Ni} / \mathrm{Co}_{3} \mathrm{O}_{4} @ \mathrm{NC}$ hybrids were synthesized via a facile impregnation-calcination process. The impregnation of $\mathrm{Ni}$ and Co ions ensured the homogeneous distribution of metals and guaranteed the production of well-dispersed $\mathrm{Ni}$ and $\mathrm{Co}_{3} \mathrm{O}_{4}$ nanoparticles by the subsequent in situ calcination reaction. The subsequent two-step calcination process constructed synergistic $\mathrm{Ni}$ and $\mathrm{Co}_{3} \mathrm{O}_{4}$ species throughout the carbon nanospheres, which prevented the aggregation and corrosion of the obtained N-doped graphitic carbon and regulated the electronic configuration of the active species. Benefiting from the intimate contact of $\mathrm{Ni}, \mathrm{Co}_{3} \mathrm{O}_{4}$, and $\mathrm{NC}$ and the efficient charge transfer among these active OER species, the obtained $\mathrm{Ni} / \mathrm{Co}_{3} \mathrm{O}_{4} @ \mathrm{NC}$ hybrids demonstrated enhanced OER activity with a smaller overpotential of $350 \mathrm{mV}$ to drive a current density of $10 \mathrm{~mA} \mathrm{~cm}^{-2}$, lower Tafel slope of $52.27 \mathrm{mV} \mathrm{dec}^{-1}$, smaller charge-transfer resistance, and higher double-layer capacitance of $25.53 \mathrm{mF} \mathrm{cm}-2$ compared to those of the unary $\mathrm{Co}_{3} \mathrm{O}_{4} @ \mathrm{NC}$ and Ni@NC metal hybrids. This work proposes a feasible route to design other heteroatom-doped oxides supported on ideal carbon materials to realize high electrocatalytic activities for the OER.

\section{References}

[1] C. Tang, H. F. Wang, Q. Zhang, Acc. Chem. Res., 2018, 51, 881-889.

[2] Z. J. Xu, Nano-Micro Lett., 2018, 10, 8.

[3] C. Wei, S. Sun, N. Mandler, X. Wang, S. Z. Qiao, Z. J. Xu, Chem. Soc. Rev., 2019, 48, 2518-2534. 


\section{Graphical Abstract}

Chin. J. Catal., 2020, 41: 1782-1789 doi: 10.1016/S1872-2067(20)63621-X

Synergistic effect of metallic nickel and cobalt oxides with nitrogen-doped carbon nanospheres for highly efficient oxygen evolution

Bin Dong *, Jing-Yi Xie, Zhi Tong, Jing-Qi Chi, Ya-Nan Zhou, Xue Ma, Zhong-Yuan Lin, Lei Wang*, Yong-Ming Chai China University of Petroleum (East China); Qingdao University of Science and Technology

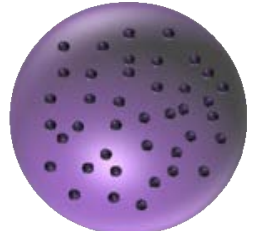

$\mathrm{Ni}^{2+}, \mathrm{Co}^{2+} @$ polymer

\section{$800^{\circ} \mathrm{C}$}

Ar gas

NiCo@NC

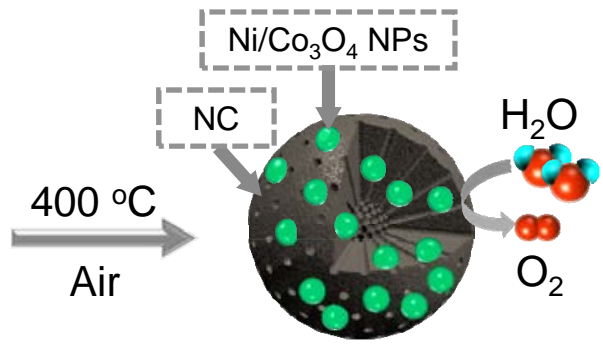

$\mathrm{Ni} / \mathrm{CO}_{3} \mathrm{O}_{4} @ \mathrm{NC}$

Well-defined $\mathrm{Ni} / \mathrm{Co}_{3} \mathrm{O}_{4}$ nanospheres coupled with $\mathrm{N}$-doped carbon hybrids $\left(\mathrm{Ni} / \mathrm{Co}_{3} \mathrm{O}_{4} @ \mathrm{NC}\right)$ have been synthesized via a facile impregnation-calcination method, and they exhibit excellent OER activity and stability in alkaline media.

[4] P. F. Cheng, T. Feng, Z. W. Liu, D. Y. Wu, J. Yang, Chin. J. Catal., 2019, $40,1147-1152$.

[5] H. Zhang, Z. Yang, W. Yu, H. Wang, W. Ma, X. Zong, C. Li, Adv. Energy Mater., 2018, 8, 1800795 .

[6] C. F. Du, Q. Liang, R. Dangol, J. Zhao, H. Ren, S. Madhavi, Q. Yan, Nano-Micro Lett., 2018,10, 67.

[7] T. Huang, T. Shen, M. Gong, S. Deng, C. Lai, X. Liu, T. Zhao, L. Teng, D. Wang, Chin. J. Catal., 2019, 40, 1867-1873.

[8] T. Wu, S. Sun, J. Song, S. Xi, Y. Du, B. Chen, W. A. Sasangka, H. Liao, C. L. Gan, G.G. Scherer, L. Zeng, H. Wang, H. Li, A. Grimaud, Z. J. Xu, Nat. Catal., 2019, 2, 763-772.

[9] X. Wang, W. Ma, C. Ding, Z. Xu, H. Wang, X. Zong, C. Li, ACS Catal,, 2018, 8, 9926-9935.

[10] F. Guo, Y. Wu, H. Chen, Y. Liu, L. Yang, X. Ai, X. Zou, Energy Environ. Sci., 2019, 12, 684-692.

[11] S. Sun, Y. Sun, Y. Zhou, S. Xi, X. Ren, B. Huang, H. Liao, L. P. Wang, Y. Du, Z. J. Xu, Angew. Chem. Int. Ed., 2019, 58, 6042-6047.

[12] J. F. Qin, M. Yang, T. S. Chen, B. Dong, S. Hou, X. Ma, Y. N. Zhou, X. L. Yang, J. Nan, Y. M. Chai, Int. J. Hydrogen Energy, 2020, 45, 2745-2753.

[13] J. Li, Q. Zhuang, P. Xu, D. Zhang, L. Wei, D. Yuan, Chin. J. Catal., 2018, 39, 1403-1410.

[14] D. Chen, M. Qiao, Y. R. Liu, L. Hao, D. Liu, C. L. Dong, Y. Li, S. Wang, Angew. Chem. Int. Ed., 2018, 57, 8691-8696.

[15] Y. Chen, H. Li, J. Wang, Y. Du, S. Xi, Y. Sun, M. Sherburne, J. W. Ager III, A. C. Fisher, Z. J. Xu, Nat. Commun., 2019, 10, 572.

[16] X. Liang, L. Shi, Y. Liu, H. Chen, R. Si, W. Yan, Q. Zhang, G. D. Li, L. Yang, X. Zou, Angew. Chem. Int. Ed., 2019, 58, 7631-7635.

[17] X. Yang, J. Chen, Y. Chen, P. Feng, H. Lai, J. Li, X. Luo, Nano-Micro Lett., 2018,10, 15.

[18] Y. Zhao, X. Zhang, X. Jia, G. I. N. Waterhouse, R. Shi, X. Zhang, F. Zhan, Y. Tao, L. Z. Wu, C. H. Tung, D. O'Hare, T. Zhang, Adv. Energy Mater., 2018, 8, 1703585.

[19] Y. Pi, Q. Shao, P. Wang, F. Lv, S. Guo, J. Guo, X. Huang, Angew. Chem. Int. Ed., 2017, 56, 4502-4506.

[20] Y. M. Chai, X. Y. Zhang, J. H. Lin, J. F. Qin, Z. Z. Liu, J. Y. Xie, B. Y. Guo,
Z. Yang, B. Dong, Int. J. Hydrogen Energy, 2019, 44, 10156-10162.

[21] J. Li, W. Xu, J. Luo, D. Zhou, D. Zhang, L. Wei, P. Xu, D. Yuan, Nano-Micro Lett., 2018, 10, 6.

[22] P. Wang, Z. Pu, Y. Li, L. Wu, Z. Tu, M. Jiang, Z. Kou, I. S. Amiinu, S. Mu, ACS Appl. Mater. Interfaces, 2017, 9, 26001-26007.

[23] L. Wei, K. Goh, Ö. Birer, H. Karahan, J. Chang, S. Zhai, X. Chen, Y. Chen, Nanoscale, 2017, 9, 4401-4408.

[24] X. Shang, B. Dong, Y. M. Chai, C. G. Liu, Sci. Bull., 2018, 63, 853-876.

[25] Y. Liu, X. Liang, L. Gu, Y. Zhang, G. D. Li, X. Zou, J. S. Chen, Nat. Commun., 2018, 9, 2609.

[26] L. Trotochaud, J. K. Ranney, K. N. Williams, S. W. Boettcher, J. Am. Chem. Soc., 2012, 134, 17253-17261.

[27] C. G. Morales-Guio, L. Liardet, X. Hu, J. Am. Chem. Soc., 2016, 138, 8946-8957.

[28] J. Q. Chi, K. L. Yan, Z. Xiao, B. Dong, X. Shang, W. K. Gao, X. Li, Y. M. Chai, C. G. Liu, Int. J. Hydrogen Energy, 2017, 42, 20599-20607.

[29] F. Xu, Z. Tang, S. Huang, L. Chen, Y. Liang, W. Mai, H. Zhong, R. Fu, D. Wu, Nat. Commun., 2015, 6, 7221.

[30] J. Q. Chi, W. K. Gao, J. H. Lin, B. Dong, J. F. Qin, Z. Z. Liu, B. Liu, Y. M. Chai, C. G. Liu, J. Catal., 2018, 360, 9-19.

[31] M. Zhang, Q. Dai, H. Zheng, M. Chen, L. Dai, Adv. Mater., 2018, 30, 1705431.

[32] J. Zhang, L. Dai, Angew. Chem. Int. Ed., 2016, 55, 13296-13300.

[33] J. Q. Chi, J. Y. Xie, W. W. Zhang, B. Dong, J. F. Qin, X. Y. Zhang, J. H. Lin, Y. M. Chai, C. G. Liu, ACS Appl. Mater. Interfaces, 2019, 11, 4047-4056.

[34] L. Wang, M. Li, Z. Huang, Y. Li, S. Qi, C. Yi, B. Yang, J. Power Sources, 2014, 264, 282-289.

[35] F. Zhang, D. Zhu, X. Chen, X. Xu, Z. Yang, C. Zou, K. Yang, S. Huang, Phys. Chem. Chem. Phys., 2014, 16, 4186-4192.

[36] X. Li, G. Q. Han, Y. R. Liu, B. Dong, W. H. Hu, X. Shang, Y. M. Chai, C. G. Liu, ACS Appl. Mater. Interfaces, 2016, 8, 20057-20066.

[37] L. A. Stern, L. Feng, F. Song, X. Hu, Energy Environ. Sci., 2015, 8, 2347-2351.

[38] K. L. Nardi, N. Yang, C. F. Dickens, A. L. Strickler, S. F. Bent, $A d v$. Energy Mater., 2015, 5, 1500412. 
[39] X. Yuan, H. Ge, X. Wang, C. Dong, W. Dong, M. S. Riaz, Z. Xu, J. Zhang, F. Huang, ACS Energy Lett., 2017, 2, 1208-1213.

[40] S. Zhang, X. Yu, F. Yan, C. Li, X. Zhang, Y. Chen, J. Mater. Chem. A, 2016, 4, 12046-12053.

[41] X. Li, Y. Fang, X. Lin, M. Tian, X. An, Y. Fu, R. Li, J. Jin, J. Ma, J. Mater.
Chem. A, 2015, 3, 17392-17402.

[42] S. Wang, J. Wang, M. Zhu, X. Bao, B. Xiao, D. Su, H. Li, Y. Wang, J. Am. Chem. Soc., 2015, 137, 15753-15759.

[43] H. Yan, C. Tian, L. Wang, A. Wu, M. Meng, L. Zhao, H. Fu, Angew. Chem. Int. Ed., 2015, 54, 6325-6329.

\title{
金属 $\mathrm{Ni}$ 和Co氧化物与 $\mathrm{N}$ 掺杂的碳球协同作用用于电解水析氧反应
}

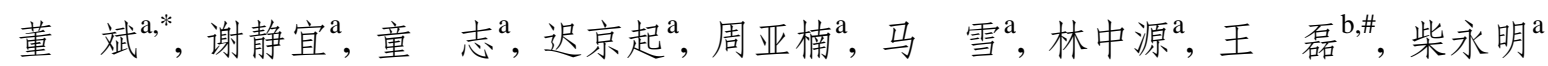 \\ a 中国石油大学(华东)理学院, 重质油加工国家重点实验室, 山东青岛 266580

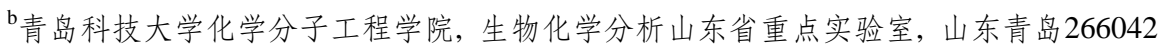

\begin{abstract}
摘要: 电解水制氢被认为是理想的清洁制氢技术, 然而, 阴阳两极过电位的存在, 特别是阳极析氧反应涉及复杂的四电子转 移过程, 阳极过电位较高, 严重制约了电解水制氢效率的提高. 因此, 研究发现高效且成本低的析氧反应电催化剂具有重要 意义. 因此, 本课题组利用温和的浸渍-热解策略合成了具有高效析氧活性的 $\mathrm{Ni}^{-} \mathrm{Co}_{3} \mathrm{O}_{4}$ 与 $\mathrm{N}$ 掺杂的碳复合电催化剂 $\left(\mathrm{Ni} / \mathrm{Co}_{3} \mathrm{O}_{4} @ \mathrm{NC}\right)$. 其中, 第一步浸渍过程将无机 $\mathrm{Ni}$ 与Co 源浸渍到聚合物纳米球结构中, 可以有效地保证热解过程中产生均匀 分散的极细 $\mathrm{Ni}_{\text {in口 }} \mathrm{Co}_{3} \mathrm{O}_{4}$ 纳米颗粒; 此外, 高温热解过程形成的 $\mathrm{N}$ 掺杂的碳基质可以有效地阻止活性组分的团聚和交联, 调控 其电子结构. 由于 $\mathrm{Ni}, \mathrm{Co}_{3} \mathrm{O}_{4}$ 和 $\mathrm{NC}$ 的协同作用, 制备得到的 $\mathrm{Ni} / \mathrm{Co}_{3} \mathrm{O}_{4} @ \mathrm{NC}$ 电催化剂在碱性溶液中均展现了比由单一金属组

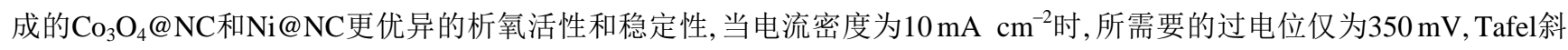
率低至 $52.27 \mathrm{mV} \mathrm{de}{ }^{-1}$, 电荷转移阻抗极小, 双电层电容高达 $25.53 \mathrm{mF} \mathrm{cm}^{-2}$. 本文采用扫描电镜(SEM), 高分辨透射电镜 (HRTEM), X射线衍射(XRD)和X射线光电子能谱(XPS)等手段研究了 $\mathrm{Ni}^{-} \mathrm{Co}_{3} \mathrm{O}_{4} @ N C$ 电催化剂的微观结构、元素组成和价态, 分析了复合 $\mathrm{Ni} / \mathrm{Co}_{3} \mathrm{O}_{4} @ \mathrm{NC}$ 电催化剂具有优异析氧性能的原因.

$\mathrm{SEM}$ 结果表明, $\mathrm{Ni} / \mathrm{Co}_{3} \mathrm{O}_{4} @ \mathrm{NC}$ 电催化剂在经历浸渍-热解过程后, 完整地继承了聚合物的纳米球状形貌, 只是平均粒径 由 $100 \mathrm{~nm}$ 缩聚为 $90 \mathrm{~nm}$ 左右, SEM mapping显示各元素均匀分散在每一个纳米球结构中. HRTEM结果显示, 紧密耦合的Ni和 $\mathrm{Co}_{3} \mathrm{O}_{4}$ 超细纳米颗粒均匀分散于纳米球结构中, 且碳基质有效地限制了这些颗粒的过度生长及团聚. XRD和XPS结果再次 印证 $\mathrm{Ni} / \mathrm{Co}_{3} \mathrm{O}_{4} @ \mathrm{NC}$ 是由 $\mathrm{Ni}_{\text {和 }} \mathrm{Co}_{3} \mathrm{O}_{4}$ 两种晶体结构构成, 此外, $\mathrm{XPS}$ 结果显示 $\mathrm{N}$ 原子成功掺杂到碳基质中, 富电子的 $\mathrm{N}$ 原子掺杂 到碳基质中可以有效地调控 $\mathrm{Ni} / \mathrm{Co}_{3} \mathrm{O}_{4} @ \mathrm{NC}$ 的电子结构, 提高本征电催化活性. 相应的催化反应结果表明, $\mathrm{Ni} / \mathrm{Co}_{3} \mathrm{O}_{4} @ \mathrm{NC}$ 相 较于单一的 $\mathrm{Co}_{3} \mathrm{O}_{4} @ \mathrm{NC}$ 和 $\mathrm{Ni} @ \mathrm{NC}$ 析氧活性更高, 这是由于 $\mathrm{Ni}$ 与 $\mathrm{Co}_{3} \mathrm{O}_{4}$ 协同作用, 使 $\mathrm{Co}_{3} \mathrm{O}_{4}$ 的 $\mathrm{Co}^{2+} \beta^{+}$氧化还原峰向阳极偏移, 从 而增加了 $\mathrm{Co}_{3} \mathrm{O}_{4}$ 的本征活性; 此外高导电性的 $\mathrm{Ni}$ 掺杂到 $\mathrm{Ni} / \mathrm{Co}_{3} \mathrm{O}_{4} @ \mathrm{NC}$ 复合物结构中, 提高了催化剂的导电性, 加快了电子传 输能力; 杂原子 $\mathrm{N}$ 的掺杂有效地调控了催化剂的电子结构, 提高了催化剂的本征活性. 总之, $\mathrm{Ni} 、 \mathrm{Co}_{3} \mathrm{O}_{4}$ 和 $\mathrm{NC}$ 的协同作用使 $\mathrm{Ni} / \mathrm{Co}_{3} \mathrm{O}_{4} @ \mathrm{NC}$ 复合物在碱性溶液中具有高效催化析氧性能. 该策略为制备杂原子掺杂的负载于高导电碳载体的氧化物基 催化剂提供了有益参考.
\end{abstract}

关键词: $\mathrm{Ni} / \mathrm{Co}_{3} \mathrm{O}_{4} @ \mathrm{NC}$; $\mathrm{N}$ 掺杂的碳; 电催化剂; 协同效应; 析氧反应

收稿日期: 2020-02-26. 接受日期: 2020-03-29. 出版日期: 2020-11-05.

*通讯联系人. 电话/传真: (0532)86981156; 电子信箱: dongbin@upc.edu.cn

\#通讯联系人. 电子信箱: inorchemwl@126.com

基金来源：山东省自然科学基金(ZR2017MB059); 国家自然科学基金(21776314); 中央高校基本科研业务费专资金 (18CX05016A); 中国石油大学研究生创新工程基金项目(YCX2019096).

本文的电子版全文由Elsevier出版社在ScienceDirect上出版(http://www.sciencedirect.com/science/journal/18722067). 